\title{
Enteropathogenic Bacteria from Padang Food in Jatinangor September-October 2012
}

\author{
Syed Anwar Husain, ${ }^{1}$ Sunarjati Sudigdoadi, ${ }^{2}$ Abdullah Firmansah ${ }^{3}$ \\ ${ }^{1}$ Faculty of Medicine Universitas Padjadjaran, ${ }^{2}$ Department of Microbiology and Parasitology \\ Faculty of Medicine Universitas Padjadjaran, ${ }^{3}$ Department of Medical Nutrition Faculty of \\ Medicine Universitas Padjadjaran
}

\begin{abstract}
Background: Diarrhea is a food borne disease and still a major health problem in Indonesia. Padang food is a popular cuisine and is exposed on an opened display, sometimes for many hours in room temperature, catering favorable conditions for bacterial growth. This study is undertaken to identify enteropathogenic bacteria on food in Padang restaurants located in Jatinangor, Sumedang

Methods: A laboratory study was conducted in the microbiology laboratory of the Department of Microbiology in the Faculty of Medicine, Universitas Padjadjaran, during September-October 2012. Samples were collected from 5 Padang restaurants located in Jatinangor using systematic random sampling. From each restaurant, 4 wet samples were collected approximately 2-4 hours after being left open on the display shelves from sambal hijau, sambal merah, gulai babat and gulai nangka, cultured in tryptic soy broth (TSB) and incubated for 24 hours at $37^{\circ} \mathrm{C}$, then inoculated in Mac Conkey agar and incubated for 24 hours at $37 \stackrel{\circ}{\circ}$. Gram-staining was performed to identify gram-negative rods. The bacteria were put through biochemical tests.

Results: Four species bacteria from the Enterobacteriaceae family were identified. The most frequent bacteria which was identified in the samples was Shigella sp ( 4 from 20), followed by Klebsiella pneumonia (3 from 20), Escherichia coli and Pseudomonas sp were less identified.

Conclusions: Various Padang foods have potential risks of bacterial contamination due to the preparation, handling, and serving. It should be considered that the prepared food should be covered and placed in food warmers, ensuring warm food for hours. [AMJ.2015;2(1):241-44]
\end{abstract}

Keywords: Contamination, enteropathogenic, food-borne disease, padang food

\section{Introduction}

Food contains the essential nutrition that needed to maintain the functions of human body such as; metabolism, growth and repairement of cell damage, regulation and protection. Inappropriate food preparation, handling and serving will result in food contamination. This situation can result the transmission of various communicable food borne diseases. ${ }^{1}$ Diarrhea is a major disease which also acts as a major mortality agent worldwide. In 1998, diarrhea was the approximated cause of the mortality of 2.2 million people, where the majority of the people were under 5 years of age (WHO, 2000). ${ }^{1}$ Annually, there is an estimated of 4 billion cases of diarrhea worldwide.

The etiology of diarrhea can range from viruses, bacteria, parasites and may also occur after ingestion of drugs and chemical toxins. Transmissions of these harmful bacteria are usually through means of vectors as well as improper preparation and handling.1 Leaving food in certain temperatures for extensive periods of time can greatly contribute to bacterial growth. ${ }^{2}$

Padang food is frequently consumed by Indonesian community and are famous for their spicy food and their unique way of serving it. ${ }^{3}$ The food is displayed in an open display and is usually stacked on plates without any cover, leaving all the food exposed to the air and vectors such as flies. ${ }^{4}$ It is important to note that the food is usually kept in the open for many hours at room temperature, which caters to favorable conditions for bacterial growth. ${ }^{2}$ Based on these obvious factors existing in many Padang restaurants, this study was undertaken to isolate and identify any enteropathogenic bacteria on Padang food in Padang restaurants located in Jatinangor, Sumedang. 
Table 1 Numbers of contaminated samples

\begin{tabular}{lc}
\hline \multicolumn{1}{c}{ Species } & Number of contaminated samples \\
\hline Escherichia coli & 2 \\
Shigella sp & 4 \\
Klebsiella pneumoniae & 3 \\
Pseudomonas sp & 2 \\
None & 9 \\
Total & 20 \\
\hline
\end{tabular}

\section{Methods}

A laboratory study was conducted in the microbiology laboratory of the Department of Microbiology in the Faculty of Medicine, Universitas Padjadjaran, Jatinangor during September-October 2012. The samples used in this study were Padang food from various Padang restaurants located in Jatinangor. From 10 Padang restaurants, a systematic random sampling was conducted to get 5 samples of the restaurants. ${ }^{4}$ From each restaurant, 4 wet samples were collected from sambal hijau, sambal merah, gulai babat and gulai nangka. The samples were collected approximately 2-4 hours after being left open on the display shelves.

The exclusion criteria were Padang restaurants which covered their food properly. After being taken the samples were brought to the laboratory, and were cultured in tryptic soy broth (TSB) and incubated for 24 hours at $37^{\circ} \mathrm{C}$. After 24 hours, the samples were inoculated in Mac Conkey agar and incubated for 24 hours at $37^{\circ} \mathrm{C} .5$

Growth of colonies in the MacConkey agar were observed in order to distinguish between lactose and non-lactose fermenters. Following that, gram-staining was performed in order to differentiate between gram-positive and gramnegative bacteria. Once the gram-negative rods bacteria were found, the bacteria were put through biochemical tests which include Kligler Iron Agar (KIA), motility, indole and urease (MIU) agar and citrate agar followed by incubation for 24 hours at $37^{\circ} \mathrm{C}$. the results are then interpreted to identify the bacteria species. ${ }^{5}$ Then the results were tabulated.

\section{Results}

Four species bacteria from the Enterobacteriaceae family were identified
(Table 1).

The most frequent bacteria which was identified in the samples was Shigella sp. followed by Klebsiella pneumonia. Although other bacteria were less identified, Escherichia coli and Pseudomonas sp should be remained as an important bacteria that can cause diarrhea.

Based on table 2, only one restaurant that had no bacteria in their food sample. There was two restaurants that had various bacteria in their food samples. Others restaurants had only one bacteria in their food samples, either Klebsiella pneumoniae or Shigella sp.

\section{Discussions}

Based on the data collected and interpreted, it can be concluded that the majority of food sampled from the Padang restaurants did contain bacteria. About 4 out of 20 samples contained pathogenic bacteria, namely Shigella. Around 2 samples contained potentially pathogenic bacteria, which was Escherichia coli. ${ }^{6}$

There are many ways the food was contaminated with these bacteria, such as improper handling, preparation, and storage of food. There also could have been possible contamination of food and utensils from vectors like flies, roaches, and other insects and pests. One of the most important catalysts for the bacteria growth was the temperature, since the food was kept in the open for more than 2 hours at room temperature. ${ }^{2}$

Among the reasons why some of the samples had no growth of bacteria could be because the food was cooked properly at the right temperature until it was fully cooked. Another probable reason was because the restaurant had taken strict measures to ensure bacterial vectors were reduced in the vicinity and that the cooks and workers practiced 
Table 2 Identification of bacteria According to the Distribution of Restaurants

\begin{tabular}{ccc}
\hline Restaurant & Sample & Bacteria Present \\
\hline 1 & a & None \\
& b & None \\
& c & None \\
2 & d & None \\
& a & Pseudomonas sp \\
& b & Klebsiella pneumoniae \\
& c & Escherichia coli \\
3 & d & Escherichia coli \\
& a & None \\
& b & Pseudomonas sp \\
& c & Shigella sp \\
& d & Klebsiella pneumoniae \\
& a & None \\
& b & None \\
& c & Klebsiella pneumoniae \\
& d & None \\
& a & Shigella sp \\
& b & Shigella sp \\
& c & None \\
& d & Shigella sp \\
\hline
\end{tabular}

Note: a: sambal hijau, b: sambal merah, c: gulai babat, d: gulai nangka

good hygiene such as cleaning the utensils and apparatus properly as well as self-hygiene.

When Escherichia coli is present, it was suspected that there is some sort of fecal contamination present in the water or even food contaminated through vectors or feces around the food preparation site. Escherichia coli is a frequent cause of bacterial infections in humans which often involve the intestine. The pathovars of the main intestinal infections include many such as Enterohemorrhagic, Enteroaggregative, and Enterotoxigenic variants among others. However the danger posed by Escherichia coli is only evident if the pathovar involved is a pathogenic type, such as the Enterohemorrhagic variant. ${ }^{8}$ This is because Escherichia coli is also a normal flora in the intestine of humans and animals alike.

Unfortunately in this research, the identification of the pathovars could not be done due to the lack of the facilities in the microbiology laboratory as well as the funds. The verification of the type of pathovar determines its potential to be a danger to humans. ${ }^{10}$

Shigella is another enteropathogenic bacteria which is closely related to Escherichia coli since they are capable in producing the harmful and potent shigatoxin during the course of an infection. ${ }^{8}$ It is a major cause of diarrhea throughout developing countries in the world, and leading cause of infant diarrhea and mortality. Transmission occurs through the fecal-oral route primarily by contamination of hands. Some of the subtypes include four species namely; Shigella dysenteriae, Shigella flexneri, Shigella sonnei and Shigella boydii. Although harmful in nature, the degree of harmfulness is influenced by the infective dose, measured in number of microorganisms, which is on the order of 103 or 1000 organisms. ${ }^{8}$ Perhaps another research should be conducted to find out the infective dose of the bacteria. Therefore the measured number of microorganisms will influence the danger level of whether it can cause serious repercussions.

Pseudomonas is a common gram negative 
bacteria which is an opportunistic human pathogen, meaning it seldom infects healthy individuals. It is mostly found in soil, water and man-made environments. Klebsiella pneumoniae is similar in most aspects and is present in the respiratory tract as well as feces of about $5 \%$ of normal individuals. ${ }^{8}$ The presence of these bacteria proves that it could be normal occurring bacteria or perhaps it is an unanticipated contamination of the sample during transportation. However, it could also be related to the improper hygiene of the restaurant.

The limitations of this study, it could not identify the species of the bacteria (pathogenic, non-pathogenic) due to limited laboratory facilities and funds.

Conclusively, various Padang foods have potential risks of bacterial contamination due to the preparation, handling, and serving as mention in this study. It should be considered that the prepared food should be covered and placed in food warmers, ensuring warm food for hours. Since there are various of Padang foods prepared in the padang restaurants, a broader study should be conducted using other types of food and more samples should be added. Moreover the samples of food should be collected several times in one day to identify the beginning of the emergence of the bacteria.

\section{References}

1. WHO. Water sanitation health. Geneva: World Health Organization;2012 [Cited 2012 May 10]. Available from: http:// www.who.int/water_sanitation_health/ diseases/diarrhoea/en/.

2. Food Safety and Inspection Service. Safe food handling. Omaha: United States Department of Agriculture; 2011 [Cited 2012 May 12]. Available from: http:// www.fsis.usda.gov/FACTSheets/Danger_ Zone/index.asp.

3. Expat Web Site Association Jakarta Indonesia. Indonesian food: a memorable Southeast Asian cuisine. Jakarta: Expat Web Site Association Jakarta Indonesia; 2011 [Cited 2012 May 15]. Available from: http://www.expat.or.id/info/ indonesianfood.html.

4. Kirk JH. Flies and disease. Davis: University of California; 2004 [Cited 2012 May 15]. Available from: http://www.vetmed. ucdavis.edu/vetext/inf-da.html.

5. Pommerville J. Alcamo's laboratory fundamentals of microbiology. 8th ed. Sudbury: Jones \& Bartlett Publishers; 2010.

6. Brooks GF, Butel JS. Jawetz, Melnick, and Adelberg's medical microbiology. 25th ed. New York: McGraw-Hill Medical; 2010. p. 237-8.

7. Feist S. Safe food handling. Arlington: The Partnership for Food Safety Education; 2010 [Cited 2012 May 12]. Available from: http://fightbac.org/.

8. Todar K. Pathogenic Escherichia coli. Madison: University of Wisconsin; 2011 [Cited 2012 November 18]. Available from: http://textbookofbacteriology. net/e.coli.html.

9. WHO. Risk characterization of microbiological hazards in food. 17th ed. Geneva: World Health Organization; 2009. p. 14-26.

10. Parija SC. Textbook of microbiology and immunology. 2nd ed. Gurgaon: Elsevier India; 2009 